\title{
Computation of Temperature Distribution in the Rotor of an Induction Motor during Reactor Starting in Two Dimensional Rectangular Co-ordinates
}

\author{
Debasis Sarkar, Nirmal Kr. Bhattacharya and Ashok Kr. Naskar
}

\begin{abstract}
In developing electric machines in general and induction motors in particular, temperature limits are a key factor affecting the efficiency of the overall design. Since conventional loading of induction motors is often expensive, the estimation of temperature rise by tools of mathematical modeling becomes increasingly important and as a result of which computational methods are widely used for estimation of temperature rise in electrical machines. The paper develops a two-dimensional transient thermal model in rectangular co-ordinates accounting for losses and that describes the thermal phenomena in the rotor of an induction motor during reactor starting. The developed model has been implemented in FEM and has been applied to predict temperature rise in a $7.5 \mathrm{~kW}$ totally enclosed fan-cooled induction motor.
\end{abstract}

Index Terms-Design Performance, FEM, Insulation, Induction Motor, Temperature rise, Thermal Analysis, Transients

\section{INTRODUCTION}

An electric machine is a complex engineering system that consists of different materials with different thermal properties and distributed heat sources. Although we witness advances achieved in many aspects of electric machine design, it is generally agreed that the development of thermal design methodologies for electric machines lags behind [16].

Traditionally, thermal studies of electrical machines have been carried out by analytical techniques, or by thermal network method [1], [2]. These techniques are useful when approximations to thermal circuit parameters and geometry are accepted. Numerical techniques based on either finite difference method [3], [4] or finite element methods [6]-[12] are more suitable for analysis of complex system. Rajagopal, M.S, Kulkarni, D.B, Seetharamu,K.N, and Ashwathnarayana P.A $[14,15]$ have carried out two-dimensional steady state and transient thermal analysis of TEFC machines using FEM.

F. A. Author is now with the Department of Electrical Engineering, IIEST, Shibpur, Howrah 711103, India

S. B. Author is now with the Department of Physics, Jadavpur University,Kolkata-32, India

T. C. Author is now with the Department of Electrical Engineering, Seacom Engineering College, Howrah-711302, India
Compared to the finite difference method finite element method can easily handle complicated boundary configurations and discontinuities in material properties.

The finite element method is first introduced for the steady state thermal analysis of the stator cores of large turbine-generators by Armor and Chari [8]. However, their works are restricted to core packages far from the ends and they do not consider the influence of the stator coil heat. In 1980, Armor [6] employed arch-shaped finite elements to solve the transient heat flow in the rotor of large turbine-generators. Sarkar et al. [7] also described a method based on arch-shaped finite elements with explicitly derived solution matrices for determining the thermal field of induction motors.

In this paper, the finite element method is used for predicting the temperature distribution in the rotor of an induction motor under reactor starting conditions, using triangular shaped finite elements with explicitly derived solution matrices. A 64-elements two-dimensional slice of armature iron, together with copper winding bounded by planes at mid-slot, mid-tooth are used for solution to a transient rotor heating problem, and this defines the scope of this technique. The model is applied to one squirrel cage TEFC machine of $7.5 \mathrm{KW}$ and the temperatures obtained are found to be within the permissible limit in terms of overall temperature rise computed from the resulting loss density distribution

\section{2-DIMENSIONAL FINITE ELEMENT FORMULATION}

The governing differential equation for transient heat conduction in rectangular co-ordinate is expressed in the general form as

$\frac{\delta}{\delta x}\left(K_{x} \frac{\delta T}{\delta x}\right)+\frac{\delta}{\delta y}\left(K_{y} \frac{\delta T}{\delta y}\right)+\tilde{Q}-P_{m} C_{m} \frac{\delta T}{\delta t}=0$

Where,

$\mathrm{K}_{\mathrm{x}}, \mathrm{K}_{\mathrm{y}}$, are the thermal conductivities in the $\mathrm{X}$ and $\mathrm{Y}$ directions respectively and $\mathrm{Q}$ is the internal heat generation i.e. energy input and $P_{m}, C_{m}$ are the material density and specific heat of the material.

On the boundary of the outer surfaces, we have the following general boundary conditions: 


$$
K_{x} \frac{\delta T}{\delta x} n_{x}+K_{y} \frac{\delta T}{\delta y} n_{y}+q+h\left(T-T_{\infty}\right)=0 \quad \mathrm{t}>0
$$

Where,

$\mathrm{n}_{\mathrm{x},} \mathrm{n}_{\mathrm{y}}$ are the direction cosines of the outward normal vector $\hat{n}$ to the boundary curve, $\mathrm{q}$ is the heat loss at the boundary due to conduction, and $\mathrm{h}\left(\mathrm{T}-\mathrm{T}_{\infty}\right)$ is the heat loss at the boundary due to convection to ambient temperature $T_{\infty}$ with convection heat transfer co-efficient $h$.

The initial condition specifies the temperature distribution at time zero,

$$
\mathrm{T}=\mathrm{T}_{0}(\mathrm{x}, \mathrm{y}), \mathrm{t}=0
$$

According to Galerkin's weighted residual approach, the weighting functions are chosen to be the same as the shape functions. The governing differential equation takes the form

$$
\begin{aligned}
& \iint_{D^{(e)}}\left(k_{x}\left[\frac{\delta N}{\delta x}\right]\{T\}^{(e)} \frac{\delta N_{i}}{\delta x}+k_{y}\left[\frac{\delta N}{\delta y}\right]\{T\}^{(e)} \frac{\delta N_{i}}{\delta y}\right) d x d y-\iint N_{i} \tilde{Q} d x d y \\
& +\frac{P_{m} C_{m}}{2 \Delta t} \iint_{D^{(e)}}\left[2\{T\}^{(e)} N_{i}-2 T_{0} N_{i}\right] d x d y+ \\
& \quad \int_{2}^{(e)}\left(q N_{i}+h\lfloor N\rfloor\{T\}^{(e)} N_{i}-h T_{\infty} N_{i}\right) d \Sigma^{(e)}=0
\end{aligned}
$$

$$
\text { for } \mathrm{i}=\mathrm{i}, \mathrm{j}, \mathrm{k}
$$

These equations when evaluated lead to the matrix equation

$$
\left[\left[S_{x}\right]+\left[S_{y}\right]+\left[S_{T}\right]+\left[S_{H}\right]\right][T]=\left[S_{T}\right]\left[T_{0}\right]+[R]+\left[S_{C}\right]
$$

\section{Where,}

$\left[\mathrm{S}_{\mathrm{x}}\right],\left[\mathrm{S}_{\mathrm{y}}\right]$ are symmetric co efficient matrices (thermal stiffness matrices), $\left[\mathrm{S}_{\mathrm{T}}\right]$ is the heat capacity matrix, $\left[\mathrm{S}_{\mathrm{H}}\right]$ is the heat convection matrix, $[\mathrm{T}]$ is the column vector of unknown temperatures, $[R]$ is the forcing function (heat source) vector, $\left[\mathrm{S}_{\mathrm{C}}\right]$ is the column vector of heat convection, $\left[\mathrm{T}_{0}\right]$ is the column vector of unknown (previous point in time) temperatures.

\section{APPLICATION TO A THREE PHASE INDUCTION MOTOR}

In the case of transient rotor heating caused by reactor starting, the transient analysis procedure is able to provide an estimate of the temperatures throughout the volume of the rotor at an interval of time required to bring the motor from rest to rated speed by providing reduced voltage and current during the starting period and as the motor has reached a sufficiently high speed near to the operating speed, rated voltage and current are provided by short circuiting the reactors during the starting action of the induction motor. Thermal conductivities of copper and insulation in the slot are taken together for simplification of calculation [8].

Assuming that the machine is at rest with its rotor winding at normal ambient temperature, respective voltage and current are injected to the stator winding of the machine. The temperatures within the volume of the rotor are calculated at the nodal points for a period of the time required for starting action.

In this analysis, because of symmetry, the 2-dimensional slice of core iron and winding, chosen for modelling the problem and the geometry, is bounded by planes passing through the mid-tooth, the mid-slot which is divided into finite elements as shown in fig. 1. Triangular elements are used throughout the solution region.

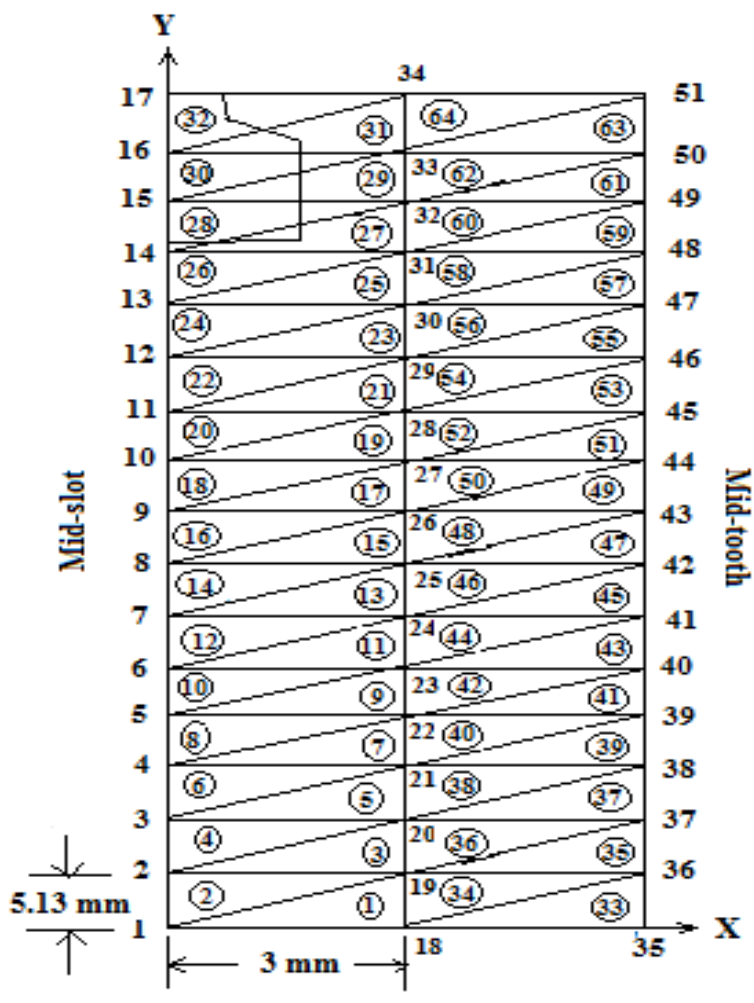

Fig.1. Slice of armature iron and winding bounded by planes at mid-slot, mid-tooth divided into triangular-shaped finite elements.

\section{CALCULATION OF HEAT LOSSES}

Heat losses in the rotor tooth and armature core are based on calculated magnetic flux densities $\left(1.0386 \mathrm{~Wb} / \mathrm{m}^{2}\right.$ and $0.731 \mathrm{~Wb} / \mathrm{m}^{2}$ respectively) in these regions. Tooth flux lines are predominantly radial and core flux lines predominantly circumferential. The gain orientation of the core punching differs in these two directions and therefore influences the heating for a given flux density. Copper losses in the winding are determined from the length as well as the area required for the conductors in the slot.

Iron loss of rotor core per unit volume $=0.0000117 \mathrm{~W} / \mathrm{mm}^{3}$. Iron loss of rotor teeth per unit volume $=0.0000315 \mathrm{~W} / \mathrm{mm}^{3}$.

\section{A. Rotor Copper Loss}

To calculate the temperature distribution in the rotor during the starting period, we will take the starting voltage at $50 \%$ of full voltage to start with and calculations will be done on that 
voltage till the reactor acts as impedance in the motor circuit. Finally, the temperature distribution within the rotor due to reduced voltage reactor starting are calculated by splitting the entire slip range (i.e. from $s=1$ to full load slip $s=0.04$ ) into small intervals.

\section{B. Calculation of winding impedance of the reactor}

Voltage across the reactor is $=239.6 \mathrm{~V}$

Using 50\% of tapping, current through the stator winding per phase $=22.37 \mathrm{~A}$.

Line current $=38.75 \mathrm{~A}$, which is the output current of the reactor. From VA balancing the input current of the reactor is $=19.38 \mathrm{~A}$. and $50 \%$ of total impedance of the reactor will be $=$ $6.18 \Omega$.The rotor current is being calculated at starting when reactor is connected in the circuit from $\mathrm{s}=1.0$ to $\mathrm{s}=0.2$.

As the stator is delta connected and $50 \%$ of full voltage is applied across the stator winding, the stator current at start $\mathrm{s}=1.0$ is given in Table I.

TABLE I: MOTOR AT STARTING

\begin{tabular}{ll}
\hline \hline Slip(s) & 1 \\
Resistance of the circuit $\left(r_{1}+r_{2}^{F} / \mathrm{s}\right)$ & $4.43 \Omega$ \\
Reactance in the circuit $\left(\mathrm{x}_{1}\right)$ & $8.15 \Omega$ \\
Impedance of the circuit $\left(\mathrm{z}_{1}\right)$ & $9.3 \Omega$ \\
stator current $\left(\mathrm{I}_{1}\right)$ & $26.85 \mathrm{~A}$ \\
Equivalent rotor current, $\left(\mathrm{I}_{2}\right)$ & $23.3595 \mathrm{~A}$
\end{tabular}

Rotor current at slip $\mathrm{s}=0.2$ is calculated when the motor is directly connected to the supply from slip $s=0.2$ to full load slip $\mathrm{s}=0.0425$.

When full voltage is provided across the stator winding by short-circuiting the reactors, the rotor current at $\mathrm{s}=0.2$ is given in Table-II.

TABLE II: MOTOR DIRECTLY CONNECTED TO THE SUPPLY

\begin{tabular}{ll}
\hline \hline Slip $(\mathrm{s})$ & 0.2 \\
Resistance of the circuit $=\mathrm{r}_{1}+\mathrm{r}_{2}^{\prime} / \mathrm{s}$ & $13.99 \Omega$ \\
Reactance in the circuit $\left(\mathrm{x}_{1}\right)$ & $8.15 \Omega$ \\
stator current $\left(\mathrm{I}_{1}\right)$ & $25.63 \mathrm{~A}$ \\
Equivalent rotor current, $\left(\mathrm{I}_{2}\right)$ & $22.2981 \mathrm{~A}$ \\
\hline
\end{tabular}

Assuming a load of moment of inertia $10 \mathrm{~kg}-\mathrm{m}^{2}$, the time required is calculated at different intervals of speed from rest, $\mathrm{s}=1$ to $\mathrm{s}=0.2$ when reactor is connected to the circuit (using $50 \%$ tapping of reactor ) and also at different intervals from $\mathrm{s}=0.2$ to $\mathrm{s}=0.04$ when stator is directly connected to the supply. The stator currents, Rotor currents, rotor copper losses and the time required for starting action at different slips are calculated and tabulated in Table III.

TABLE III: THE DIFFERENT VALUES OF ROTOR CURRENT, STATOR CURRENT, ROTOR COPPER LOSS/SLOT/UNIT VOLUME AND TIME REQUIRED FOR STARTING ACTION AT DIFFERENT SLIPS IN REACTOR STARTING

\begin{tabular}{|c|c|c|c|c|c|}
\hline $\begin{array}{c}\text { Starting } \\
\text { period }\end{array}$ & $\begin{array}{l}\text { Slip } \\
\text { (s) }\end{array}$ & $\begin{array}{c}\text { Stator } \\
\text { Current } \\
\text { (Amp) }\end{array}$ & $\begin{array}{c}\text { Rotor } \\
\text { Current } \\
\text { (Amp) }\end{array}$ & $\begin{array}{c}\text { Rotor Copper } \\
\text { loss/slot/unit } \\
\text { volume }\left(\mathrm{W} / \mathrm{mm}^{3}\right)\end{array}$ & $\begin{array}{l}\text { Time } \\
(\mathrm{sec})\end{array}$ \\
\hline 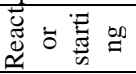 & $\begin{array}{l}1 \\
0.9 \\
\end{array}$ & $\begin{array}{l}26.85 \\
26.6 \\
\end{array}$ & $\begin{array}{l}23.3595 \\
23.142 \\
\end{array}$ & $\begin{array}{l}0.0007077 \\
0.0007038 \\
\end{array}$ & 4.29 \\
\hline
\end{tabular}

\begin{tabular}{|c|c|c|c|c|c|}
\hline & & & & & 3.88 \\
\hline & 0.8 & 26.3 & 22.881 & 0.0006991 & \\
\hline & 0.7 & 25.9 & 22.533 & 0.0006929 & \\
\hline & & & & & 3.09 \\
\hline & 0.6 & 25.4 & 22.098 & 0.0006850 & \\
\hline & 0.5 & 24.7 & 21.489 & 0.0006739 & \\
\hline & & & & & 2.33 \\
\hline & 0.4 & 23.56 & 20.4972 & 0.0006557 & 199 \\
\hline & 0.3 & 21.75 & 18.9225 & 0.0006257 & \\
\hline & 0.2 & 18.55 & 16.1385 & 0.0005717 & 1.7 \\
\hline & 0.2 & 25.63 & 22.2981 & 0.0006886 & 1975 \\
\hline $\bar{z}$ & 0.1 & 15.26 & 13.2762 & 0.0005117 & \\
\hline ○् & 0.04 & 6.66 & 5.7942 & 0.0003140 & 1.222 \\
\hline
\end{tabular}

V. CONVECTIVE HEAT TRANSFER COEFFICIENT $[6,7]$

Consider only one convective heat transfer co-efficient which is the forced convection for turbulent flow in the rectangular air gap surface is taken as $\mathrm{h}=58.8760136 \mathrm{~W} / \mathrm{m}^{2}{ }^{\circ} \mathrm{C}$.

\section{THERMAL CONSTANTS $[7,8]$}

In two dimensional transient problems, the following properties are taken for each different element material.

a) Thermal conductivity, $\mathrm{X}$-direction, $V_{x} \mathrm{~W} / \mathrm{m}{ }^{\circ} \mathrm{C}$

b) Thermal conductivity, $\mathrm{Y}$-direction, $V_{y} \mathrm{~W} / \mathrm{m}{ }^{\circ} \mathrm{C}$

c) Material density, $P_{m} \mathrm{Kg} / \mathrm{m}^{3}$

d) Material specific heat, $C_{m} \mathrm{~W}-\mathrm{S} / \mathrm{Kg}{ }^{\circ} \mathrm{C}$

TABLE IV: TyPICAL SET OF MATERIAL PROPERTIES FOR INDUCTION MOTOR ROTOR

\begin{tabular}{ccc}
\hline \hline & Magnetic Steel Wedge & Copper \&Insulation \\
\hline$K x$ & 33.070 & 2.007 \\
$K_{y}$ & 0.8260 & 1.062 \\
$P_{m}$ & 7.86120 & 8.9684 \\
$C_{m}$ & 523.589 & 385.361 \\
\hline \hline
\end{tabular}

\section{RESULTS AND DISCUSSIONS}

Computation are done for the two-dimensional rectangular rotor structure with maximum permissible temperature and then calculating the heat transfer co-efficient at the mean of the two temperatures as tabulated below in Table V. Since the hottest spots are found to be in the rotor copper as envisaged from the calculated temperatures for the two-dimensional structure during the reactor starting, the temperature variation with time in each node of copper is taken as an index to understand the temperature profile during the transient. It is to be noted that the temperature is found to be maximum at the nodes pertaining to copper in the axis of symmetry at mid-slot as has been shown in fig. 2 to fig. 11 . 


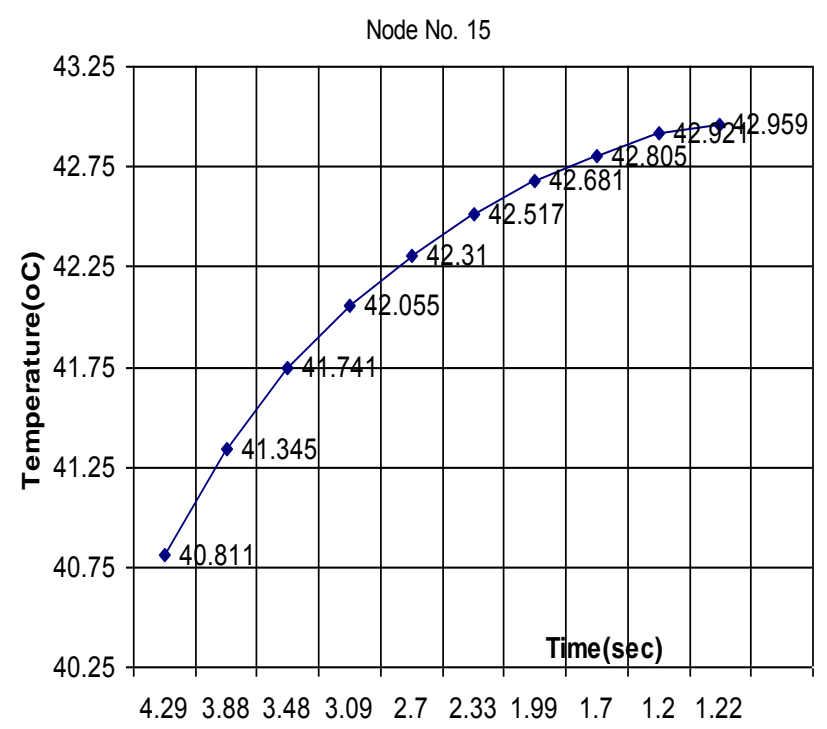

Fig. 2. Corresponding nodal temperature vs. time

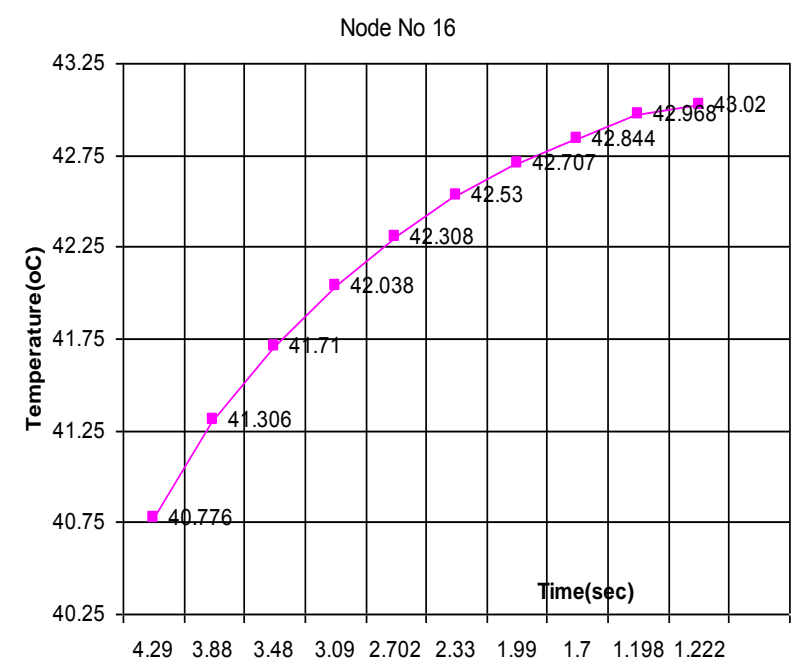

Fig. 3. Corresponding nodal temperature vs. time

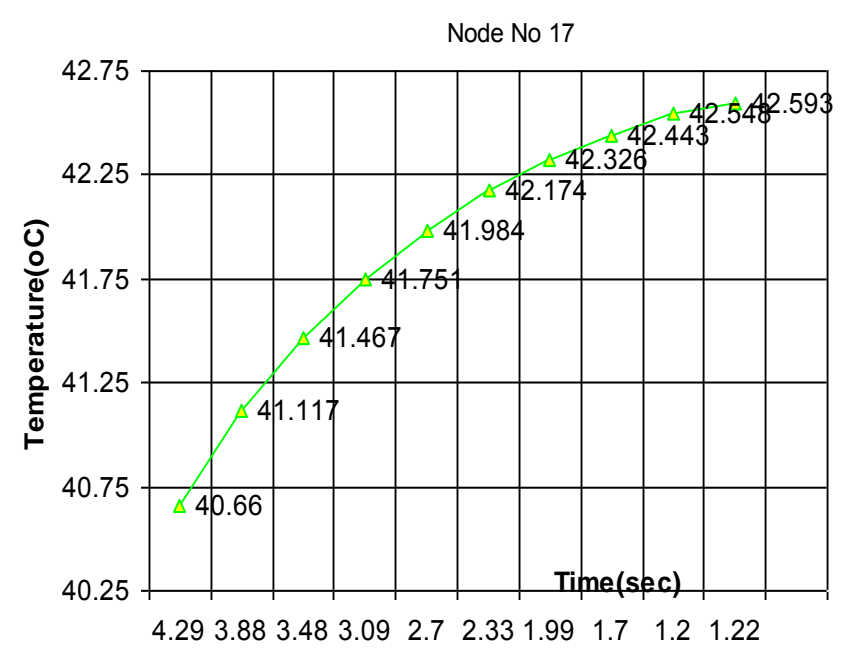

Fig. 4. Corresponding nodal temperature vs. time

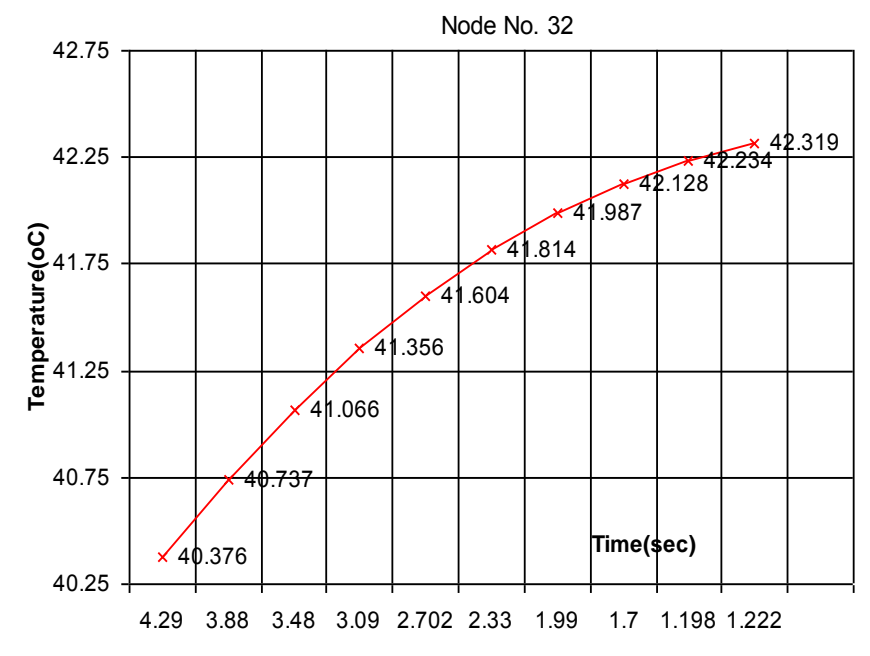

Fig. 5. Corresponding nodal temperature vs. time 


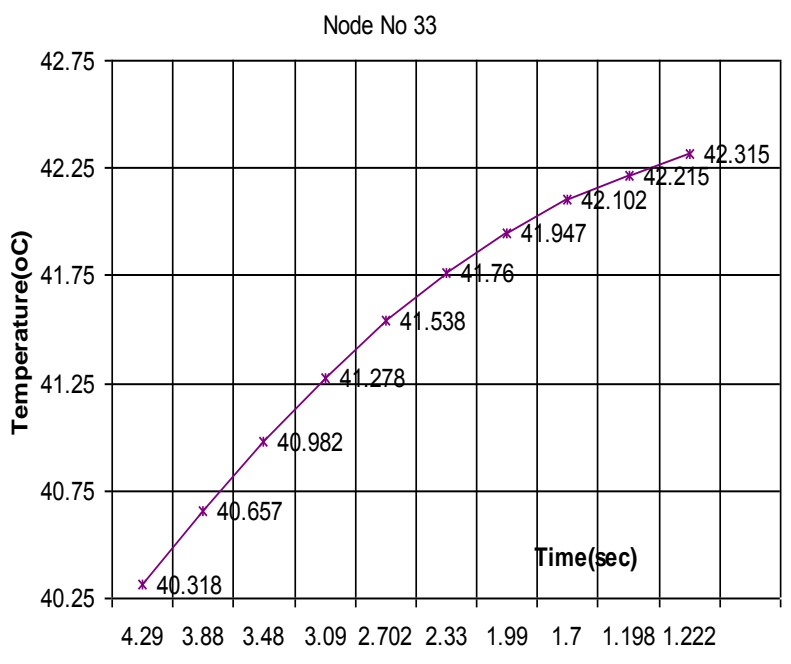

Fig. 6. Corresponding nodal temperature vs. time

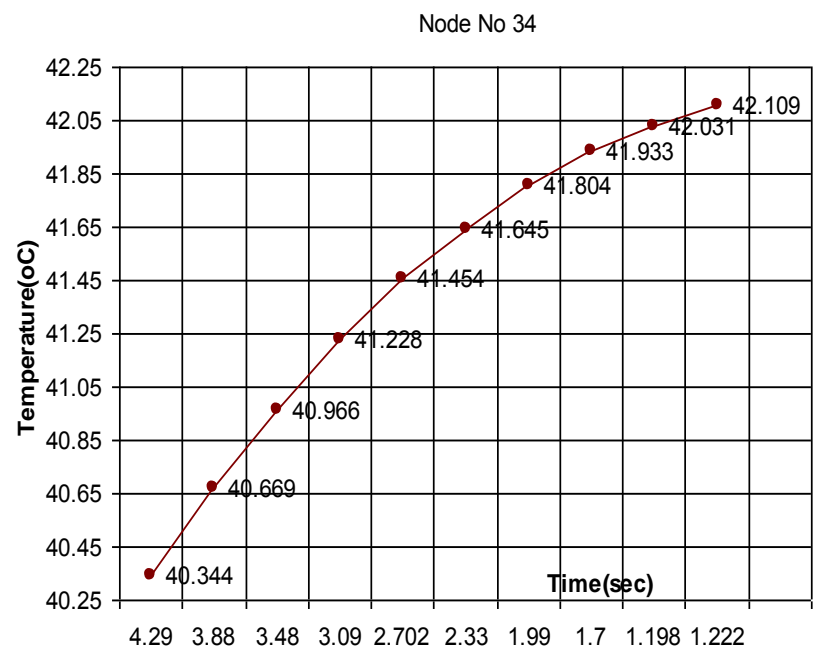

Fig. 7. Corresponding nodal temperature vs. time

Node No 49

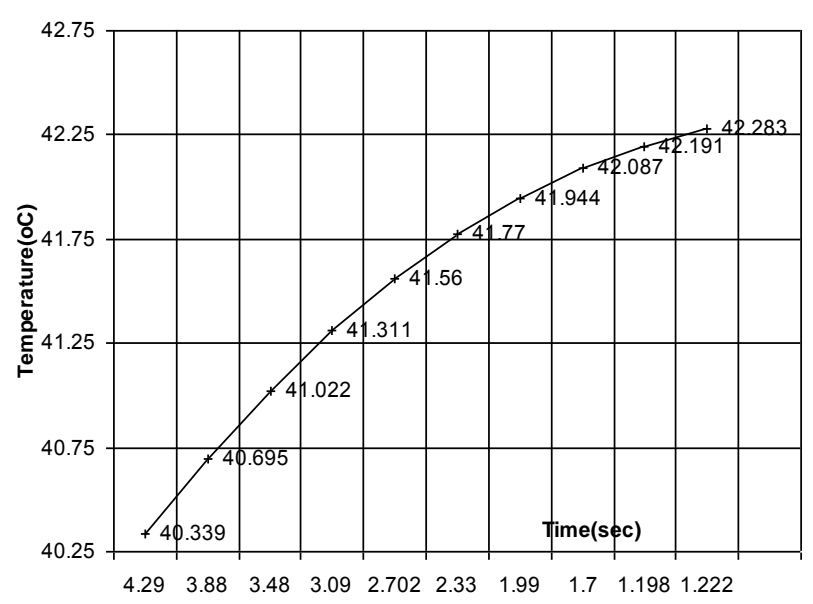

Fig. 8. Corresponding nodal temperature vs. time

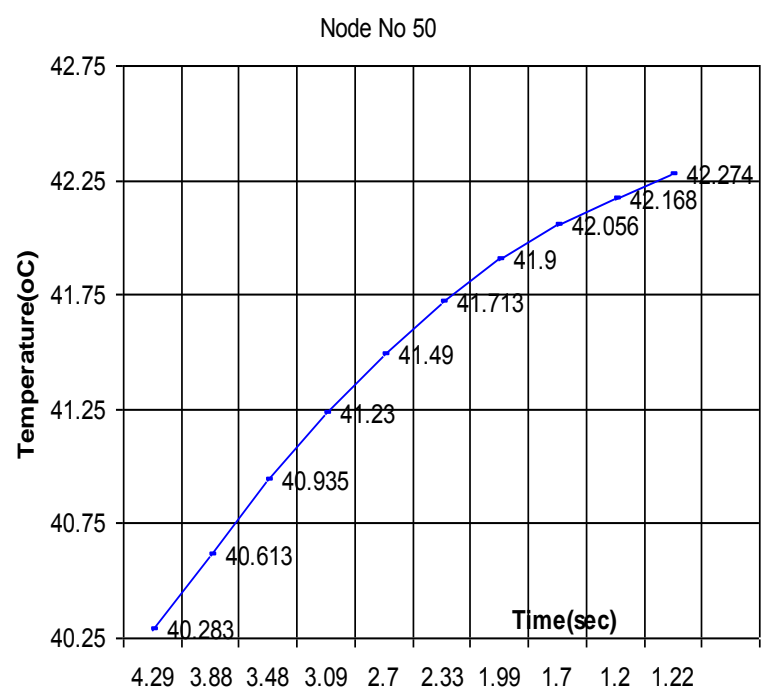

Fig. 9. Corresponding nodal temperature vs. time

Node No 51

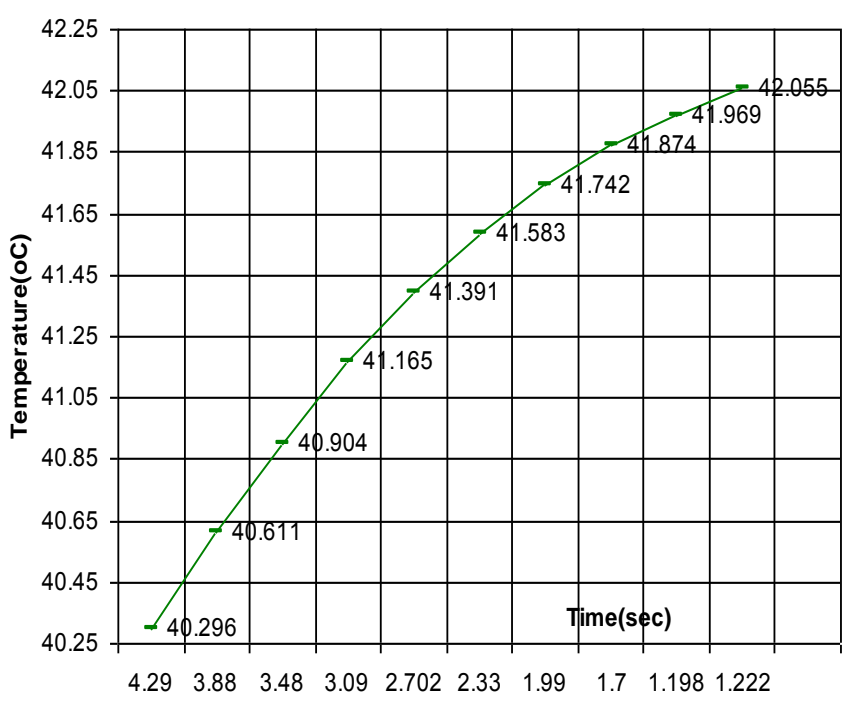

Fig. 10. Corresponding nodal temperature vs. time 


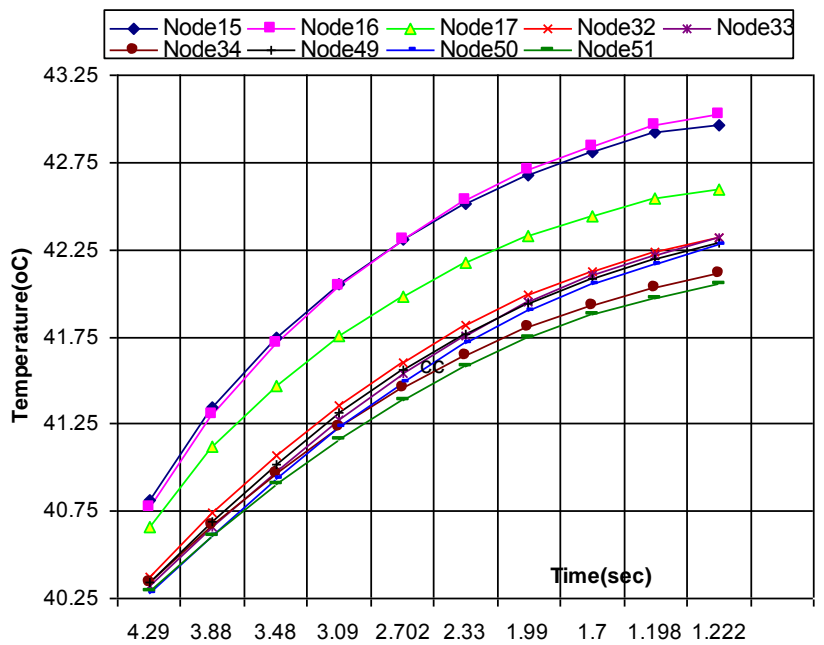

Fig. 11. Corresponding nodal temperature vs time

\section{CONCLUSION}

The two-dimensional transient finite element procedure for

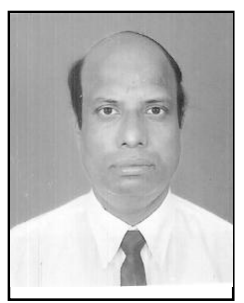

First A. D.Sarkar(SM'03) received B.E. and M.E. degree in Electrical Engineering from Calcutta University, Calcutta, in 1975 and 1979, respectively. He was engaged in teaching assignment and research activities in I.I.Ts from 1979-1981 and served as Lecturer in B.I.T.S Pilani from 1981-1983. He received the Ph.D degree in electrical engineering fron Jadavpur University, Jadavpur, Kolkata in 1991. He is currently senior professor at the department of Electrical Engineering Bengal Engineering and Science University, Shibpur, Howrah, India. He is the author of valuable papers published in referred international journals and international conference proceedings. His research interests include design and optimization of electromagnetic devices, application of advanced numerical techniques to analysis and design of electrical machines.

the thermal analysis of large induction-motor rotors in Cartesian co-ordinates provides the opportunity for the in-depth studies of rotor heating problems. By virtue of the new, explicitly derived triangular element, together with an efficient bandwidth and Gauss routine [5], extremely large problems can be efficiently solved.

A new two-dimensional finite element procedure in rectangular co-ordinates, with explicitly derived solution matrices, has been applied to the solution of the transient heat conduction equation during reactor starting. Though the results are approximate, the method is fast, inexpensive and leads itself to immediate visual pictures of the temperature pattern in a two-dimensional slice of iron core and winding in the rotor of an induction motor.

\section{REFERENCES}

[1] G. M. Rosenberry, "The transient stalled temperature rise of cast aluminum squirrel-cage rotors for induction motors," AIEE Trans., vol. PAS-74, Oct. 1955.

[2] T. J. Roberts, "The solution of the heat flow equations in large electrical machines," Proc. Instn. Mech. Engrs., pt. 3E, vol. 184, pp. 70-83, 1969-1970.

http://dx.doi.org/10.1243/pime_conf_1969_184_128_02
[3] K. Reichert, "The calculation of the temperature distribution in electrical machines with the aid of the finite difference method," Elektro Tech Z-A, Bd 90, H6, 1969.

[4] C. E. Tindall and S. Brankin, "Loss-at-source thermal modeling in salient pole alternators using 3-dimensional finite difference techniques," IEEE Trans. Magnetics, vol. 24, no. 1, Jan. 1988.

[5] L.L. Bhirud, Matrix operations on the computer, Bombay, Oxford \& IBH Publishing Co., 1975.

[6] A. F. Armor, "Transient, three-dimensional, finite element analysis of heat flow in turbine-generator rotors," IEEE Trans. PAS-99, no. 3, pp. 934-946, May/June 1980.

[7] D.Sarkar and N.K.Bhattacharya, "Approximate analysis of transient heat conduction in an induction motor during star-delta starting" in Proc. IEEE Int. Conf. on industrial technology (ICIT2006), Dec., PP.1601-1606.

[8] A.F. Armor, , and M. V. K. Chari, "Heat flow in the stator core of large turbine generators by the method of three-dimensional finite elements, Part-I: Analysis by Scalar potential formulation: Part - II: Temperature distribution in the stator iron," IEEE Trans,Vol. PAS-95, No. 5, pp.1648-1668, September 1976.

[9] C.C. Hwang, S. S. Wu, and. Y. H. Jiang, "Novel Approach to the Solution of Temperature Distribution in the Stator of an Induction Motor" IEEE Trans. on energy conversion, Vol. 15, No. 4, December 2000.

[10] A. F.Armor, "Transient Three Dimensional Finite Element Analysis of Heat Flow in Turbine-Generator Rotors", IEEE Transactions on Power Apparatus and Systems, Vol. PAS 99, No.3 May/June. 1980.

[11] J. Nerg, "Thermal Modeling of a High-Speed Solid-Rotor Induction Motor" Proceedings of the 5th WSEAS International Conference on Applications of Electrical Engineering, Prague, Czech Republic, March 12-14, pp90-95, 2006.

[12] K. H. Huebner, E. A. Thorton, and T. G. Byrom, The Finite Element Method for Engineers, Third ed: John Wiley \& Sons, 1995.

[13] Chang-Chou Hwang; S. S. Wu; Y. H. Jiang; 'Novel Approach to the Solution of Temperature Distribution in the Stator of an Induction Motor' IEEE Transaction on Energy Conversion, Vol. 15, NO. 4, December 2000.

[14] ,M.S. Rajagopal, D.B. Kulkarni, , K.N. Seetharamu and P.A. Ashwathnarayana,"Axi-symmetric steady state thermal analysis of totally enclosed fan cooled induction motors using FEM", $2^{\text {nd }}$ Nat Conf.on CAD/CAM,19-20 Aug,1994.

[15] M.S. Rajagopal, K.N. Seetharamu and P.A. Ashwathnarayana, "Transient thermal analysis of induction Motors, IEEE Trans Energyconversion, Vol.13, No.1, March1998.

[16] A. Bousbaine, 'Thermal modelling of induction motors based on accurate loss density distribution', Electrical Machines Power Syst. 27, 311-324, 1999.

http://dx.doi.org/10.1080/073135699269325

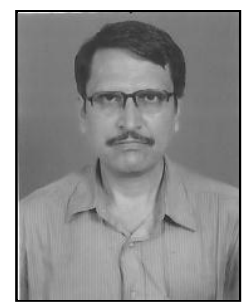

Second B. N.K. Bhattacharya received B.E degree in Electrical Engineering from Jadavpur University, Kolkata-32, West Bengal, India in 1996 and M.E degree in Electrical Engineering from Bengal Engineering College (Deemed University), Shibpur, Howrah, West Bengal, India in 2000. He is a staff member of Jadavpur University, Kolkata-32, India since 1991. He serves as a part time lecturer in Government College of Engineering and Textile Technology, Serampore, Hooglhy, West Bengal, India from 2005 to 2011. His research interests include application of advanced numerical techniques to analysis and design of electrical machines and power system. 


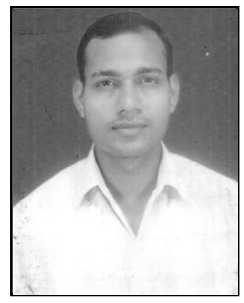

Third C. A. K. Naskar received B.Tech degree in Electrical Engineering from West Bengal University of Technology, West Bengal, in 2006 and M.E. degree in Electrical Engineering from Bengal Engineering and Science University, Shibpur, Howrah, in 2008, respectively. He received Ph.D degree in electrical engineering fron I.I.E.S.T, Shibpur, Howrah, India. He served as Lecturer in I.M.P.S Engineering College and Technology from 2008-2009. He is currently Asst. Professor and head of the department at the department of Electrical Engineering, Seacom Engineering College, Howrah, India. His research interests include application of advanced numerical techniques to analysis and design of electrical machines.

TABLE V. SOLUTION FOR Two DimEnSIONAL Rotor StRUCTURE

\begin{tabular}{|c|c|c|c|c|c|c|c|c|c|c|c|}
\hline \multirow{6}{*}{$\begin{array}{l}\bar{\delta} \\
\bar{\Xi} \\
z \\
z \\
\overline{0} \\
z\end{array}$} & \multirow{6}{*}{ 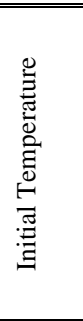 } & \multicolumn{10}{|c|}{$\begin{array}{c}\text { Temperatures exceeding } 40.283^{\circ} \mathrm{C} \text { in } 1^{\text {st }} \text { time step with convection in two-dimensional structure of totally enclosed machine for different rotor current during Reactor } \\
\text { starting. }\end{array}$} \\
\hline & & \multicolumn{8}{|c|}{ Reactor starting period } & \multicolumn{2}{|c|}{ D.O.L running period } \\
\hline & & $\mathrm{Q}=0.00070$ & $\mathrm{Q}=0.000703$ & $\mathrm{Q}=0.000699$ & $\mathrm{Q}=0.00069$ & $\mathrm{Q}=0.000685$ & $\mathrm{Q}=0.00067$ & $\mathrm{Q}=0.000655$ & $\mathrm{Q}=0.00062$ & $\mathrm{Q}=0.000688$ & $\mathrm{Q}=0.000511$ \\
\hline & & 77 & 8 & 1 & 29 & 0 & 39 & 7 & 57 & 6 & 7 \\
\hline & & $\mathrm{I}=23.3595 \mathrm{~A}$ & $\mathrm{I}=23.142 \mathrm{~A}$ & $\mathrm{I}=22.881 \mathrm{~A}$ & $\mathrm{I}=22.533 \mathrm{~A}$ & $\mathrm{I}=22.098 \mathrm{~A}$ & $\mathrm{I}=21.489 \mathrm{~A}$ & $\mathrm{I}=20.4972$ & $\mathrm{I}=18.9225$ & $=22.29$ & $\mathrm{I}=13.2762 \mathrm{~A}$ \\
\hline & & $\begin{array}{c}\text { Starting } \\
\text { time }=4.29 \\
\mathrm{~S}\end{array}$ & $\begin{array}{c}\text { Starting } \\
\text { time }=3.88 \mathrm{~S}\end{array}$ & $\begin{array}{c}\text { Starting } \\
\text { time }=3.48 \mathrm{~S}\end{array}$ & $\begin{array}{c}\text { Starting } \\
\text { time }=3.09 \\
\mathrm{~S}\end{array}$ & $\begin{array}{c}\text { Starting } \\
\text { time }=2.702 \\
\mathrm{~S}\end{array}$ & $\begin{array}{c}\text { Starting } \\
\text { time }=2.33 \\
\mathrm{~S}\end{array}$ & $\begin{array}{c}\text { Starting } \\
\text { time }=1.99 \mathrm{~S}\end{array}$ & $\begin{array}{c}\mathrm{A} \\
\text { Starting } \\
\text { time }=1.7 \mathrm{~S}\end{array}$ & $\begin{array}{l}\text { Starting time }= \\
1.1975 \mathrm{~S}\end{array}$ & $\begin{array}{c}\text { Starting } \\
\text { time }=1.222 \\
\mathrm{~S}\end{array}$ \\
\hline 15 & $40^{\circ} \mathrm{C}$ & $40.811^{\circ} \mathrm{C}$ & $41.345^{\circ} \mathrm{C}$ & $41.741^{\circ} \mathrm{C}$ & $42.055^{\circ} \mathrm{C}$ & $42.310^{\circ} \mathrm{C}$ & $42.517^{\circ} \mathrm{C}$ & $42.681^{\circ} \mathrm{C}$ & $42.805^{\circ} \mathrm{C}$ & $42.921^{\circ} \mathrm{C}$ & $42.959^{\circ} \mathrm{C}$ \\
\hline 16 & $40^{\circ} \mathrm{C}$ & $40.776^{\circ} \mathrm{C}$ & $41.306^{\circ} \mathrm{C}$ & $41.710^{\circ} \mathrm{C}$ & $42.038^{\circ} \mathrm{C}$ & $42.308^{\circ} \mathrm{C}$ & $42.530^{\circ} \mathrm{C}$ & $42.707^{\circ} \mathrm{C}$ & $42.844^{\circ} \mathrm{C}$ & $42.968^{\circ} \mathrm{C}$ & $43.020^{\circ} \mathrm{C}$ \\
\hline 17 & $40^{\circ} \mathrm{C}$ & $40.660^{\circ} \mathrm{C}$ & $7^{\circ} \mathrm{C}$ & 41. & 41.7 & $41.984^{\circ} \mathrm{C}$ & 42.1 & $26^{\circ} \mathrm{C}$ & 42.44 & $42.548^{\circ} \mathrm{C}$ & $42.593^{\circ} \mathrm{C}$ \\
\hline 32 & $40^{\circ} \mathrm{C}$ & 40 & ${ }^{\circ} \mathrm{C}$ & $C$ & $\mathrm{C}$ & $04^{\circ} \mathrm{C}$ & 41 & ${ }^{\circ} \mathrm{C}$ & 42 & $42.234^{\circ} \mathrm{C}$ & $42.319^{\circ} \mathrm{C}$ \\
\hline 33 & $40^{\circ} \mathrm{C}$ & $40.318^{\circ} \mathrm{C}$ & $40.657^{\circ} \mathrm{C}$ & $40.982^{\circ} \mathrm{C}$ & $41.278^{\circ} \mathrm{C}$ & $41.538^{\circ} \mathrm{C}$ & $41.760^{\circ} \mathrm{C}$ & $41.947^{\circ} \mathrm{C}$ & $42.102^{\circ} \mathrm{C}$ & $42.215^{\circ} \mathrm{C}$ & $42.315^{\circ} \mathrm{C}$ \\
\hline 34 & $40^{\circ} \mathrm{C}$ & $40.344^{\circ} \mathrm{C}$ & $40.669^{\circ} \mathrm{C}$ & $40.966^{\circ} \mathrm{C}$ & $41.228^{\circ} \mathrm{C}$ & $41.454^{\circ} \mathrm{C}$ & $41.645^{\circ} \mathrm{C}$ & $41.804^{\circ} \mathrm{C}$ & $41.933^{\circ} \mathrm{C}$ & $42.031^{\circ} \mathrm{C}$ & $42.109^{\circ} \mathrm{C}$ \\
\hline 49 & $40^{\circ} \mathrm{C}$ & $40.339^{\circ} \mathrm{C}$ & $40.695^{\circ} \mathrm{C}$ & $41.022^{\circ} \mathrm{C}$ & $41.311^{\circ} \mathrm{C}$ & $41.560^{\circ} \mathrm{C}$ & $41.770^{\circ} \mathrm{C}$ & $41.944^{\circ} \mathrm{C}$ & $42.087^{\circ} \mathrm{C}$ & $42.191^{\circ} \mathrm{C}$ & $42.283^{\circ} \mathrm{C}$ \\
\hline 50 & $40^{\circ} \mathrm{C}$ & $40.283^{\circ} \mathrm{C}$ & $40.613^{\circ} \mathrm{C}$ & $40.935^{\circ} \mathrm{C}$ & $41.230^{\circ} \mathrm{C}$ & $41.490^{\circ} \mathrm{C}$ & $41.713^{\circ} \mathrm{C}$ & $41.900^{\circ} \mathrm{C}$ & $42.056^{\circ} \mathrm{C}$ & $42.168^{\circ} \mathrm{C}$ & $42.274^{\circ} \mathrm{C}$ \\
\hline 51 & $40^{\circ} \mathrm{C}$ & $40.296^{\circ} \mathrm{C}$ & $40.611^{\circ} \mathrm{C}$ & $40.904^{\circ} \mathrm{C}$ & $41.165^{\circ} \mathrm{C}$ & $41.391^{\circ} \mathrm{C}$ & $41.583^{\circ} \mathrm{C}$ & $41.742^{\circ} \mathrm{C}$ & $41.874^{\circ} \mathrm{C}$ & $41.969^{\circ} \mathrm{C}$ & $42.055^{\circ} \mathrm{C}$ \\
\hline
\end{tabular}

